\title{
Effect of different substrates on rooting and shoot development of juvenile stem cuttings of Nauclea diderrichii (De Wild \& T. Durand) Merrill
}

\author{
Roseline Gusua CASPA ${ }^{1^{*}}$, Lazare KUOUDIEKONG ${ }^{1}$, Bekwake Alfred NWEGUEH ${ }^{1}$, \\ Simon TENKU NJEUDENG ${ }^{1}$, Jean Claude LAHJOU ${ }^{1}$ and Joseph ONANA ${ }^{2}$ \\ ${ }^{I}$ Institute of Agricultural Research for Development (IRAD) Nkolbisson, P.O. Box 2123, Yaounde, Cameroon. \\ ${ }^{2}$ IRAD Bertoua, P.O. Box 203 Bertoua, Cameroon. \\ *Corresponding author, E-mail: rosegusua@yahoo.com, Tel: (237) 77651942
}

\begin{abstract}
The effects of substrates on rooting of juvenile stem cuttings of Nauclea diderrichii (De Wild \& T. Durand) Merrill were investigated in non-mist high humidity propagators. Rooting ability, root development and shoot characteristics were assessed. Nine weeks after setting (WAS) of cuttings, 92\% rooted on fine sand, against $73 \%$ on saw dust. Callus production was $4.5 \%$ and $5.5 \%$ on fine sand and saw dust. Cuttings on 2:1 soil/sharp sand mixture died by the second week after setting. Mean results revealed that number of main roots (10.31) on fine sand was significantly higher than on saw dust (5.63) $(\mathrm{P}=0.00)$. A significant difference was observed between the longest main roots on fine sand $(7.68 \mathrm{~cm})$ and saw dust $(6.68 \mathrm{~cm})(\mathrm{P}=0.00)$. Number of first branch sub roots was significantly higher on fine sand (33) than saw dust (13) $(\mathrm{P}=0.05)$. The longest sub root $(6 \mathrm{~cm})$ on fine sand did not differ significantly from that on saw dust $(5.43 \mathrm{~cm})(\mathrm{P}=0.07)$. Shoot characteristics, measured 3, 5, 7 and 9 WAS all increased progressively. Highly significant $(\mathrm{P}<0.05)$ correlations were observed for root and shoot characteristics. Nauclea diderrichii cuttings perform better on fine sand than saw dust without hormones.

(C) 2009 International Formulae Group. All rights reserved.
\end{abstract}

Keywords: Vegetative propagation, rooting ability, shoot characteristics, non-mist high humidity propagator.

\section{INTRODUCTION}

Nauclea diderrichii (De Wild \& $\mathrm{T}$. Durand) Merrill is a member of the Rubiaceae family and is found in most of West Africa including Cameroon. Its natural habitat is sub tropical or tropical moist lowland forests (Keay, 1989). It is threatened by habitat loss and is included in the IUCN red list of threatened species with a vulnerable status (African Workshop, 1998). The stem is of good form, slender, straight, usually branchless, and cylindrical up to a height of between 24 and $30 \mathrm{~m}$ and has low or no buttresses (Hawthorne, 1995; Wagenfuhr, 2000). The branches are often horizontal and in whorls. Nauclea diderrichii has a broad spherical crown with thick foliage (Depuy and Mille 1993). Nauclea wood is hard and very attractive. Naturally, it is very durable, the heartwood being resistant to attack by marine borers and termites (Wagenfuhr, 2000).

The seeds which are produced in large fleshy fruits are very small in size, difficult to extract and have short viability. The small seedlings produced from seed germination of this species take a long time ( 7 to 8 months) in the nursery before attainment of transplantable size (personal observation). Taking into consideration the allogamous nature of its flowers (Letouzey, 1983), plants produced from seeds are not genetically identical to the mother plant. This factor is one of the main constraints in the propagation of phenotypically superior accessions encountered in certain forest ecologies. Like many tropical trees, relatively little is known 
about the biology of Nauclea diderrichii. As a result of the irregularity of flowering and fruiting and the high susceptibility of seeds to various pest and disease attacks, viable seeds are not always available for reforestation activities (Howland and Bowen, 1977). Leaky (1987) reported this phenomenon as one of the main limiting factors to the propagation of many forest species around the world. According to Onyekwelu et al. (2003), artificial regeneration of Nauclea diderrichii has become necessary due to the difficulty of regenerating it naturally as well as the problem of extinction which faces the species. Consequently development of other methods of propagation that will reproduce new true to type planting material in a large scale and at minimal cost (Meunier et al. 2006) is absolutely necessary. Zobel and Talbert (1984) noted that vegetative propagation in forestry is the only alternative to ensure sufficiency in planting stock and the multiplication of desired genotypes. There exist four principal methods of vegetative propagation: cuttings, grafting, layering and in vitro culture. Vegetative propagation by cuttings is however, the main technique applied to most plants as it is the case here with Nauclea diderrichii. The success of this technique does not only depend on the intrinsic aptitude of the species to root, but also on the environmental conditions in the nursery among which the nature of the substrate is fundamental (Hartmann et al. 1990); hence, the importance of testing the rooting ability of Nauclea diderrichii cuttings on three most available substrates and the behavior of young shoots after rooting. This study investigates the possibility of rooting Nauclea diderrichii juvenile stem cuttings on different nursery substrates, and growth response of resulting young plants. More specifically, the study was carried out to determine the effects of three nursery substrates on the rooting ability, root system development, evolution of the shoot system as well as the interrelation between root and shoot characteristics.

\section{MATERIALS AND METHODS \\ Plant material and treatments}

Plant material used in this trial consisted of cuttings from one and a half year old seedlings in the nursery. The seedlings were raised from Nauclea diderrichii seeds collected from 'Plus' (phenotypically superior) trees in the forest of the South region of Cameroon and sown in the forestry nursery of the Institute of Agricultural Research for Development (IRAD) in April 2007. The selected seedlings were cut back at $40 \mathrm{~cm}$ from the soil level to induce the development of coppice shoots as source of cuttings (Mesen et al. 1997). Cuttings used were juvenile shoot fragments of $5 \mathrm{~cm}$ long; with a single node and a half leaf collected some few minutes before setting in the nonmist high humidity propagator as described by Leaky et al. (1990). Experimental treatments consisted of three different substrates: fine sand, decomposed sawdust and a 2:1 mixture of soil/sharp sand.

\section{Experimental layout}

The propagator was divided into nine compartments, three of which were assigned randomly to each of the three substrates, making a total of three compartments per treatment. Thirty cuttings were set in each compartment, and a total of ninety cuttings per substrate. Two hundred and seventy cuttings were used in the trial.

\section{Observations and measurements}

Cuttings were observed for the appearance of new shoots. Number of leaves per cutting was counted visually; while shoot height and diameter were measured using a ruler and caliper respectively at two weeks interval from the third to the ninth week after cuttings were set. At nine weeks after setting (WAS) of cuttings, each compartment was flooded with water to loosen the particles and free the roots from the substrate in order to measure rooting parameters. The number of main roots from each cutting and first branch sub roots from main roots was counted; the lengths of the longest main and sub roots were measured using a ruler.

\section{Statistical analysis}

To assess the rooting ability of Nauclea diderrichii juvenile cuttings in two substrates, the percentage of rooted cuttings were computed in each case and compared using ttest for two independent samples. Mutivariate analysis of variance (Manova) procedures of SPSS V.12 were used to assess the effects of 
substrates on the root system characteristics: number of main roots, length of the longest main root, number of first branch sub roots and length of the longest sub root. The Wilks lamda criteria and the F-test were used to test respectively the overall effect and the simple effects of substrates on the 4 characteristics. For significant effects, mean differences between the substrates were compared using the Least Significant Difference (LSD) test.

\section{RESULTS}

All the cuttings set on the 2:1 mixture of soil/sharp sand died out completely by the end of the second week after they were set and therefore could not be included in further analysis.

\section{Rooting ability}

The rooting ability of juvenile cuttings in two substrates, fine sand and saw dust was evaluated using the percentage of rooted cuttings in each medium.

Figure 1 presents the distribution of cuttings in two substrates according to their individual status nine weeks after setting (WAS) in the propagator. On fine sand, 92\% of the 90 cuttings set rooted, in contrast to only $73 \%$ on saw dust. On the other hand, death was reported more on cuttings on saw dust, $18 \%$ against $3 \%$ only in fine sand. The percentage of cuttings that developed only callus were slightly similar in the two substrates, $4.5 \%$ and $5.5 \%$ respectively in fine sand and saw dust. The Fisher exact test shows that the two distributions were significantly different (Chi-2 = 1.84; $\mathrm{p}=0.002$ ), confirming an eventual relation between substrates and the behavior of cuttings after setting.

\section{Development of the root system}

The main characteristics of the root system evaluated for the two substrates were number and length of main roots; and number and length of first branch sub roots. Mean difference between the 2 substrates on the 4 root system characteristics are presented in table 1 below.

Results show that for the four characteristics, cuttings grown on fine sand had the highest means.

Differences observed in the 4 characteristics suggest that substrates have an effect on the development of the root system. The overall effect of substrates on the interrelationship of the four root characteristics were found to be highly significant based on the Wilks lambda statistics $[\mathrm{F}(4,146)=39.99, \mathrm{p}=0.000]$. This result confirms that the substrates used significantly affected the development of the root system at least on one of the 4 variables measured: number of main roots, length of the longest main root, number of first branch sub roots and length of the longest sub root. Univariate tests of the substrate effects on the 4 variables separately was shown to be statistically significant ( $p<0.004)$, except on the length of the longest sub root $(\mathrm{p}=0.073)$. From the above results it can be seen that fine sand induced more main roots (10.31) on Nauclea diderrichii cuttings than saw dust (5.63). The difference, $4.68 \pm 0.44$ found in the number of main roots was significant $(\mathrm{p}=$ 0.00 ), with a $95 \%$ confidence interval ranging from 3.81 to 5.55 roots. The mean main root length on fine sand was longer than on saw dust, $7.68 \mathrm{~cm}$ against $6.68 \mathrm{~cm}$. The difference in length although small, $1 \pm 0.34 \mathrm{~cm}$ was statistically significant $(\mathrm{p}=0.00)$. The mean number of first branch sub roots was higher on cuttings grown on fine sand than those on saw dust, 33 and 13 respectively. The difference of about $20 \pm 2$ first branch sub roots is statistically significant $(\mathrm{p}=0.05)$, and can range from 16 to 24 first branch sub roots per cutting. With the longest sub root mean length of $6 \mathrm{~cm}$, cuttings grown on fine sand had longer sub roots than those set on saw dust; but the difference in length, $0.57 \mathrm{~cm}$ was not significant $(\mathrm{p}=0.07)$.

\section{Evolution of shoot system characteristics}

To evaluate the influence of substrates on the evolution of the shoot system, three main characteristics were assessed; the shoot length $(\mathrm{cm})$, the shoot diameter $(\mathrm{mm})$ and the number of leaves at 3, 5, 7 and 9 weeks after setting (WAS) of cuttings.

Mean shoot length, diameter and number of leaves per cutting were computed and plotted against time in weeks after setting (Figure 2).

The three graphs obtained showed the same tendency, an increase in the shoot length, diameter and number of leaves with time from the third to the ninth weeks. Shoots were longer on fine sand than on saw dust. Length varied from $2 \mathrm{~cm}$ at 3 WAS to $5 \mathrm{~cm}$ at 9 WAS on fine sand while on saw dust the variation was from $1 \mathrm{~cm}$ to $4 \mathrm{~cm}$ only. The 


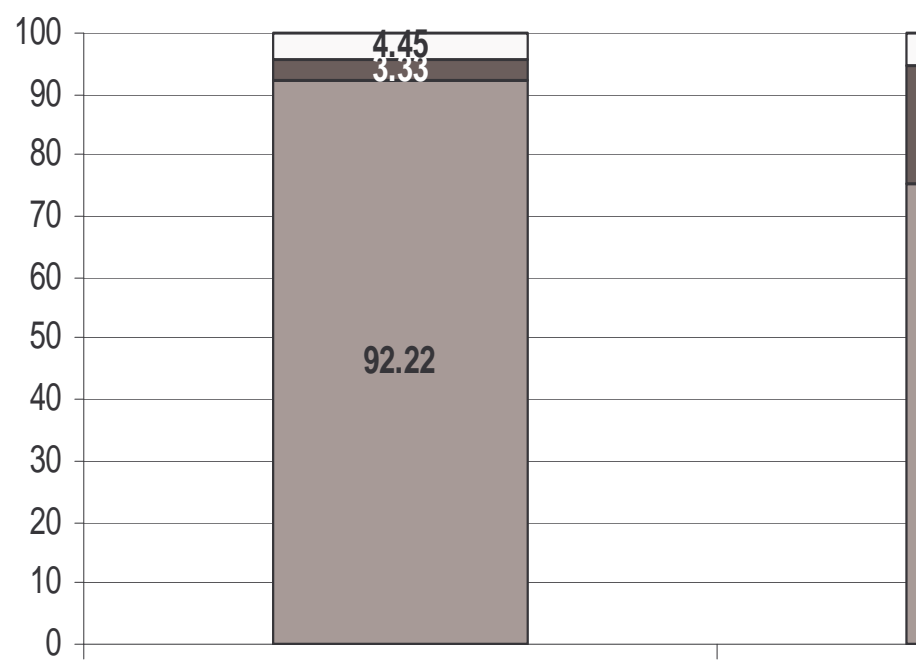

Fine sand

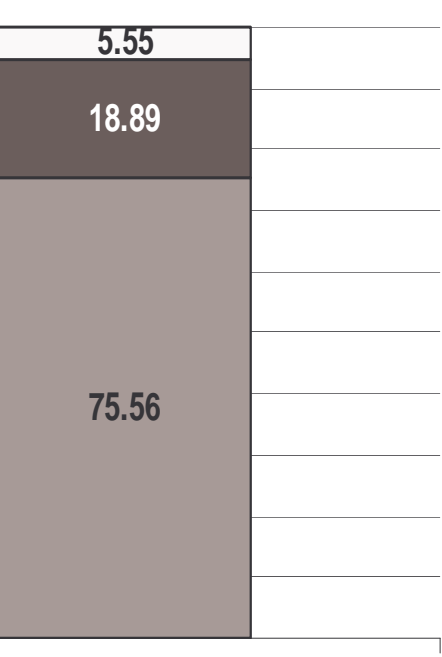

Saw dust

\section{$\square$ Rooted $\square$ Dead $\square$ Callused}

Figure 1: Distribution of Nauclea diderrichii cuttings in two substrates according to their status 9 weeks after setting in the propagator.

Table 1: Mean root system characteristics of Nauclea diderrichii cuttings on fine sand and saw dust 9 weeks after setting.

\begin{tabular}{|c|c|c|c|c|c|c|c|}
\hline \multirow{2}{*}{ Variables } & \multicolumn{2}{|c|}{ Substrate } & \multirow[b]{2}{*}{$\begin{array}{c}\text { Mean } \\
\text { difference }\end{array}$} & \multirow[b]{2}{*}{$\begin{array}{l}\text { Standard } \\
\text { deviation }\end{array}$} & \multirow[b]{2}{*}{$\begin{array}{c}\text { p- } \\
\text { value }\end{array}$} & \multicolumn{2}{|c|}{$\begin{array}{c}\text { 95\% confidence } \\
\text { interval }\end{array}$} \\
\hline & $\begin{array}{l}\text { Fine } \\
\text { sand }\end{array}$ & $\begin{array}{l}\text { Saw } \\
\text { dust }\end{array}$ & & & & $\begin{array}{l}\text { Lower } \\
\text { limit }\end{array}$ & $\begin{array}{l}\text { Upper } \\
\text { limit }\end{array}$ \\
\hline Number of main roots & 10.31 & 5.63 & $4.68^{*}$ & 0.44 & 0.00 & 3.81 & 5.55 \\
\hline $\begin{array}{l}\text { Length of the longest } \\
\text { main root }(\mathrm{cm})\end{array}$ & 7.68 & 6.68 & $1.00 *$ & 0.34 & 0.00 & 0.32 & 1.67 \\
\hline $\begin{array}{l}\text { Number of first branched } \\
\text { sub root }\end{array}$ & 33.31 & 13.48 & $19.83^{*}$ & 1.96 & 0.00 & 15.96 & 23.70 \\
\hline $\begin{array}{l}\text { Length of longest sub } \\
\text { root }(\mathrm{cm})\end{array}$ & 6.00 & 5.43 & $0.57 \mathrm{~ns}$ & 0.32 & 0.07 & -0.05 & 1.20 \\
\hline
\end{tabular}



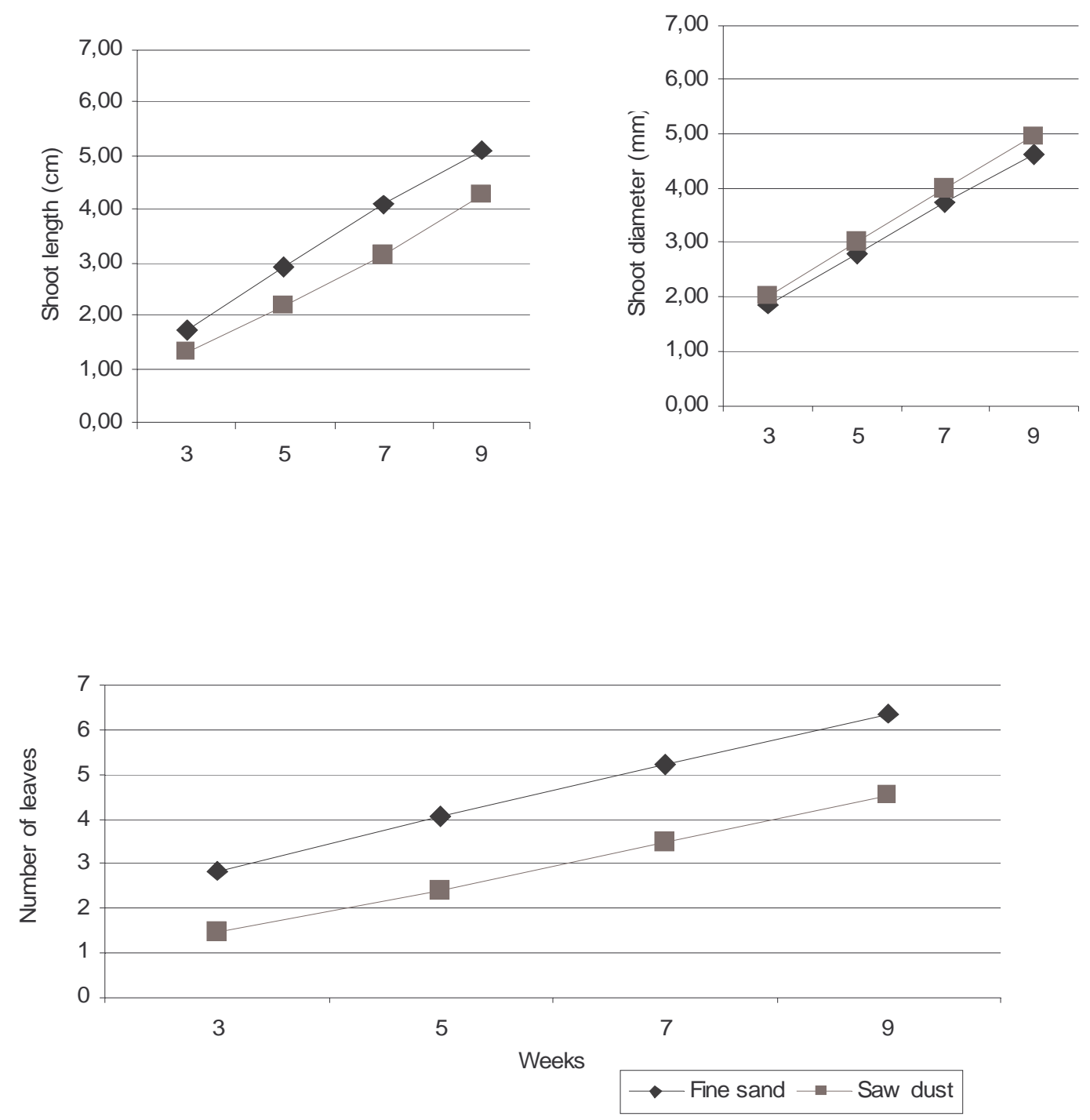

Figure 2: Evolution of Nauclea diderrichii shoot system characteristics within the first 9 weeks in the propagator.

same trend was observed for the number of leaves per cutting; on fine sand this number varied from 3 at 3 WAS to 6 at 9 WAS; while on saw dust the variation was just from about 1 to 4 at nine weeks after setting of cuttings. On the contrary, shoot diameter was slightly bigger on saw dust than on fine sand. In order to assess the significance of the difference in shoot characteristics on the two substrates, mean differences were computed and compared using the t-test as shown in table 2 .
Results obtained show that differences in shoot length between cuttings set on fine sand and those set on saw dust were highly significant $(\mathrm{p}=0.00): 0.42,0.71,0.92$ and $0.84 \mathrm{~cm}$ respectively at $3,5,7$ and 9 WAS. The number of leaves was also higher on cuttings set on fine sand compared to those on saw dust; differences although small were statistically significant $(p=0.00)$ and ranged from 1 leaf at 3 WAS to about 2 leaves at 9 WAS. In terms of diameter, differences were 
Table 2: Evolution of shoot system characteristics of rooted cuttings of Nauclea diderrichii in the nursery during the first 9 weeks after setting (WAS).

\begin{tabular}{|c|c|c|c|c|c|c|c|c|}
\hline \multirow[b]{2}{*}{ Variables } & \multicolumn{4}{|c|}{ Substrates } & \multirow[b]{2}{*}{$\begin{array}{l}\text { Standard } \\
\text { error }\end{array}$} & \multirow[b]{2}{*}{$\begin{array}{c}\text { p- } \\
\text { value }\end{array}$} & \multicolumn{2}{|c|}{$\begin{array}{l}\text { 95\% Confidence } \\
\text { interval }\end{array}$} \\
\hline & Date & $\begin{array}{l}\text { Fine } \\
\text { sand }\end{array}$ & $\begin{array}{l}\text { Saw } \\
\text { dust }\end{array}$ & $\begin{array}{l}\text { Mean } \\
\text { difference }\end{array}$ & & & $\begin{array}{l}\text { Lower } \\
\text { limit }\end{array}$ & $\begin{array}{l}\text { Upper } \\
\text { limit }\end{array}$ \\
\hline \multirow{4}{*}{$\begin{array}{l}\text { Shoot } \\
\text { length (cm) }\end{array}$} & 3 WAS & 1.72 & 1.30 & $0.42(*)$ & 0.07 & 0.00 & 0.28 & 0.55 \\
\hline & 5 WAS & 2.89 & 2.18 & $0.71(*)$ & 0.09 & 0.00 & 0.53 & 0.89 \\
\hline & 7 WAS & 4.05 & 3.13 & $0.92(*)$ & 0.12 & 0.00 & 0.68 & 1.15 \\
\hline & 9 WAS & 5.08 & 4.24 & $0.84(*)$ & 0.14 & 0.00 & 0.56 & 1.11 \\
\hline \multirow{4}{*}{$\begin{array}{l}\text { Shoot } \\
\text { diameter } \\
(\mathrm{mm})\end{array}$} & 3 WAS & 1.90 & 1.98 & $-0.08 \mathrm{~ns}$ & 0.08 & 0.32 & -0.25 & 0.08 \\
\hline & 5 WAS & 2.80 & 3.00 & $-0.20 \mathrm{~ns}$ & 0.09 & 0.05 & -0.36 & 0.01 \\
\hline & 7 WAS & 3.75 & 3.97 & $-0.22(*)$ & 0.10 & 0.03 & -0.42 & -0.02 \\
\hline & 9 WAS & 4.61 & 4.92 & $-0.31(*)$ & 0.11 & 0.04 & -0.51 & -0.10 \\
\hline \multirow{4}{*}{$\begin{array}{l}\text { Number of } \\
\text { leaves }\end{array}$} & 3 WAS & 2.82 & 1.48 & $1,34(*)$ & 0.13 & 0.00 & 1.09 & 1.59 \\
\hline & 5 WAS & 4.07 & 2.38 & $1,69(*)$ & 0.13 & 0.00 & 1.43 & 1.92 \\
\hline & 7 WAS & 5.23 & 3.47 & $1,76\left(^{*}\right)$ & 0.13 & 0.00 & 1.51 & 2.02 \\
\hline & 9 WAS & 6.36 & 4.49 & $1,86(*)$ & 0.14 & 0.00 & 1.59 & 2.13 \\
\hline
\end{tabular}

not significant $(\mathrm{P}>0.05)$ between cuttings from the two substrates for the first 5 WAS, but from the 7 th week, cuttings grown on saw dust had bigger diameters than those grown on fine sand, differences of $0.22 \mathrm{~mm}$ at 7 weeks and $0.31 \mathrm{~mm}$ at 9 weeks were significant $(\mathrm{p}=$ 0.05). These differences observed in the performance of cuttings grown on the two mediums confirm that substrates have a significant effect on the development of the shoot system. Fine sand induces longer shoots and more leaves than saw dust. Saw dust on the contrary induces bigger shoots but only from the 7 th week after setting.

\section{Correlations between root and shoot systems characteristics}

Results of the analysis of correlation (Table 3) revealed that almost all the six characteristics measured, except shoot diameter are inter correlated.

Highly significant $(\mathrm{p}<0.05)$ correlations $(\mathrm{r}>50 \%$ ) were found between number of first branch sub roots and shoot length $(55 \%)$, number of main roots $(72 \%)$, length of the longest main root $(50 \%)$; length of the longest main root and number of main roots; length of the longest sub root and the number of sub roots.

\section{DISCUSSION}

The importance of propagation medium for the rooting of leafy cuttings is widely recognized (Hartmann et al. 1990). According to Anderson (1986), an appropriate rooting medium is described as one with an optimal volume of gas-filled pore space and an oxygen diffusion rate adequate for the needs of respiration. This is possibly the case with fine sand which had a higher percentage of rooted cuttings, more and longer roots per cutting; and more robust shoots compared to saw dust. It is also clear that the provision of sufficient water to prevent wilting is a prime requirement (Loach, 1986). Fine sand has the ability to retain moisture but not water logged. Tree species seem to differ in their response to different rooting mediums. Shiembo et al. (1996) and Ofori et al. (1996) show that saw dust produces a higher rooting percentage for Irvingia gabonensis and Milicia excelsa respectively, contrasting the results obtained here with Nauclea diderrichii which produced a higher rooting percentage on fine sand; but in line with Mesen et al. (1997), who recorded a better rooting percentage for Cordia alliodora on fine sand than on saw dust. Media with relatively high water content like saw dust are generally associated with higher rates of water uptake in the cuttings (Loach, 1986) and consequently higher rooting percentages. 
Table 3: Correlations between shoot and root system characteristics.

Shoot
$\begin{aligned} & \text { length } \\ & \text { Variables }\end{aligned}$

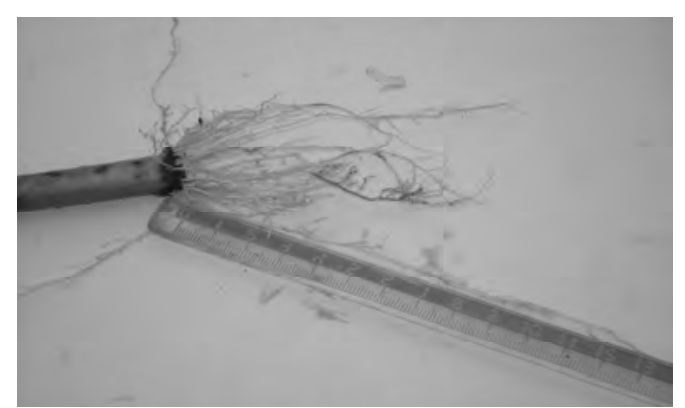

Figure 3: Rooted cutting of Nauclea diderrichii at 9 weeks after setting on fine sand.

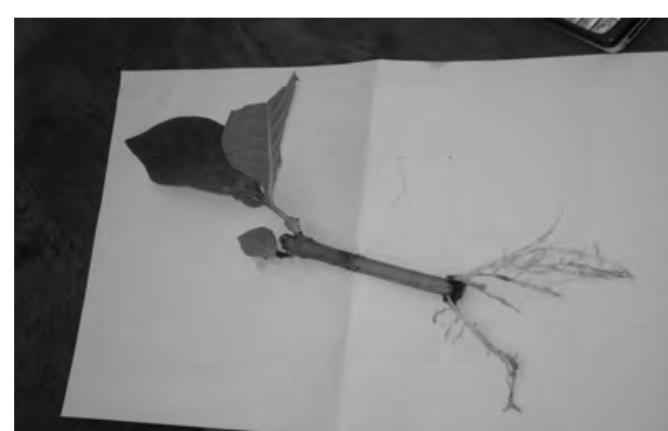

Figure 4: Rooted cutting of Nauclea diderrichii at 9 weeks after setting on saw dust.

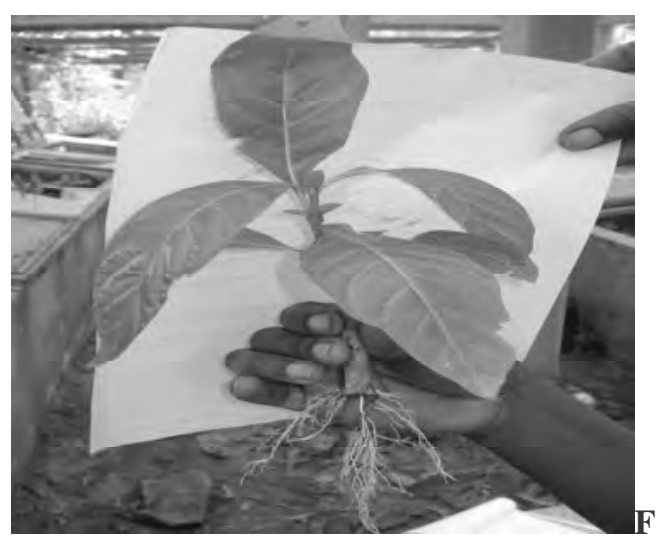

igure 5: Vigorous young plant of Nauclea diderrichii at 9 weeks after setting on fine sand.

However, water can present a major diffusion barrier to oxygen and excess water may result in anoxia within the cutting base (Loach, 1986). Some of the cutting bases in saw dust and most in 2:1 mixture of soil/sharp sand were observed to have rotted in this experiment, probably due to oxygen deficit. The fewer roots per rooted cutting recorded in saw dust may also reflect anoxia, as recorded in Chrysanthemum cuttings by Hartmann et al. (1990). 
The progressive increase in shoot characteristics with time in both substrates is an indication of growth, which is a common characteristic of biological organisms (Akinnagbe and Oni, 2007).

Results of correlation are in line with the assertion of Fogg (1970) that activities of the various meristematic cells are correlated, and the correlation is such that as the shoot increases in length, it also increases in thickness, while the root system extends proportionally. Through this study, the possibility of propagating Nauclea diderrichii by cuttings without the use of rooting hormones as has been the usual practice is established. This agrees with (Lo, 1985) who states that successful rooting without applied auxin has been reported in some tropical trees such as Shorea macrophylla. Rooting is possible either on decomposed saw dust or on fine sand, but on fine sand, the yield in terms of number of rooted cuttings, root and shoot development is better than on saw dust. Eventual cases of death of cuttings can occur on saw dust and consequently decrease the rooting percentage. If the substrate is composed of a mixture of soil and sharp sand in 2:1 ratio, due probably to anoxia or some unidentified reason, death occurs precociously and rooting is no more possible. It might be interesting to repeat this trial with soil/sharp sand mixture of $1: 1$ or $1: 2$, and a mixture of saw dust which has high water content (Mesen et al. 1997) and sand, since according to Browse (1992), sand is an aerating agent and allows adequate drainage. In conclusion, Nauclea diderrichii cuttings can root without the application of rooting hormones. With its capacity to induce more roots, a dense root system and the ability to develop a vigorous shoot system, fine sand can be recommended as the best substrate for the rapid production of true to type Nauclea diderrichii planting material at low cost using juvenile, single node half leaf cuttings.

\section{REFERENCES}

African Regional Workshop, 1998. Conservation and Sustainable Management of Trees, Zimbabwe; Nauclea diderrichii. http://www.unepwcmc.org/trade/afz_bip.htm

Akinnagbe A, Oni O. 2007. Quantitative variations in the growth of progeny seedlings of Prosopis africana (Guill., Perrott. and Rich.) plus trees in Nigeria. African Journal of Biotechnology, 6(4): 359-363.

Anderson AS. 1986. Stockplant Conditions. In New Root Formation in Plants and Cuttings, Jackson MB (ed). Martinus Nijhoff: Dordretch; 223-255.

Browse PM. 1992. Plant Propagation (Revised edn). Michellin House: London

Depuy D, Mille G. 1993. Timber plantations in the humid tropics of Africa. FAO Forestry paper 98 . FAO Rome.

Fogg GE. 1970. The Growth of Plants. Penguin Books Ltd: England.

Hartmann HT, Kester DE, Davis FT. 1990. Plant Propagation: Principles and Practices (5th edn). Prentice Hall: Englewood Cliff, HJ.

Hawthorne WD. 1995. Ecological Profiles of Ghanaian Forest Trees. Oxford Forestry Institute: Oxford.

Howland P, Bowen MR. 1977. Triplochiton scleroxylon K. Schum. and other West African tropical hardwoods. (West African hardwoods Improvement Project, Research Report, 1971-1977) Ibadan: Forestry Research Institute of Nigeria.

Keay RWJ. 1989. Trees of Nigeria (Revised edn), Clarendon Press: Oxford.

Leaky RRB. 1987. Clonal forestry in the tropics: a review of developments, strategies and opportunities, Commonwealth Forestry Review, 66.

Leaky RRB, Mesen JF, Tchoundjeu Z, Longman KA, Dick J, Newton AC, Martin A, Grace J, Munro RC, Muthoka PN. 1990. Low-technology techniques for the propagation of tropical trees. Commonwealth Forestry Review, 69: 247-257.

Letouzey R. 1983. Manuel de Botanique Forestière. Centre Technique Forestier Tropical.

Lo YN. 1985. Root initiation of Shorea macrophylla cuttings: effects of node position, growth regulators and misting regime. Forest Ecology and Management, 12: $43-52$.

Loach K. 1986. Rooting of cuttings in relation to the propagation medium. Proc. Int. Plant Propagators' Society, 35.

Mesen F, Newton AC, Leaky RRB. 1997. Vegetative propagation of Cordia 
alliodora (Ruiz \& Pavon) Oken: The effects of IBA concentration, propagation medium and cutting origin. Forest Ecology and management, 92: 45-54.

Meunier Q, Bellefontaine R, Boffa JM, Bitahwa N. 2006. Low-cost vegetative propagation of trees and shrubs: Technical handbook for Ugandan rural communities, 36 .

Ofori D, Newton AC, Leakey RRB, Grace J. 1996. Vegetative propagation of Milicia excelsa Welw by leafy stem cuttings: effects of auxin concentration, leaf area and rooting medium. Forest Ecology and Management, 84: 39-48.
Onyekwelu JC, Kateb H, Stimm B, Mosandl R. 2003. Growth characteristics of Nauclea diderrichii (De Wild \& T. Durand) Merr. in unthinned plantations in South-Western Nigeria. http://w3.forst.tumunchen.de/ waldbau/litorg0/314.pdf

Shiembo PN, Newton AC, Leaky RRB. 1996. Vegetative propagation of Irvingia gabonensis, a West African Fruit Tree. Forest Ecology and Management, 87: 185-192.

Wagenfuhr R. 2000. Holzatlas 5. Auflage. Fachbuchverlag Liepzig im Carl Hanser Verlag, Munchen 707.

Zobel B, Talbert JA. 1984. Applied Forest Tree Improvement. Wiley: New York. 